\title{
Effect of Entonox for pain management in labor: A systematic review and meta-analysis of randomized controlled trials
}

\author{
Sepideh Gareh Sheyklo ${ }^{1}$, Sakineh Hajebrahimi ${ }^{2}$, Ahmad Moosavi $^{3}$, Fatemeh Pournaghi-Azar ${ }^{4}$, Saber Azami-
} Aghdash $^{5}$, Morteza Ghojazadeh ${ }^{6}$

\footnotetext{
${ }^{1}$ Assistant Professor, Department of Obstetrics and Gynecology, Dezful University of Medical Sciences, Dezful, Iran

${ }^{2}$ Professor, Research Center for Evidence Based Medicine (RCEBM), Tabriz University of Medical Sciences, Tabriz, Iran

${ }^{3}$ Associate Professor, Department of Health and Community Medicine, Dezful University of Medical Sciences, Dezful, Iran

${ }^{4}$ Assistant Professor, Dental and Periodontal Research Centre, Tabriz University of Medical Sciences, Tabriz, Iran

${ }^{5}$ Tabriz Health Services Management Research Center, Tabriz University of Medical Sciences, Tabriz, Iran

${ }^{6}$ Associate Professor, Research Center for Evidence Based Medicine (RCEBM), Tabriz University of Medical Sciences, Tabriz, Iran
}

Type of article: Meta-analysis

\begin{abstract}
Background and aim: Entonox was one of the important methods for pain management in the delivery process. In previous years some studies have assessed the effect of this method in Iran. In this regard, the aim of this study was to systematically review studies addressing the effect of Entonox for pain management in labor.

Methods: This systematic review and meta-analysis study was conducted in 2016. The required data was collected using keywords such as "Entonox", "nitrous oxide", "vaginal delivery", "pain relief", "obstetric", "labor pain", and "labor analgesia", from databases including Google scholar, PubMed, Science Direct, Magiran, SID, and Scopus, and hand-searching of related and valid journals and references of articles. Articles published from 2000 to 2016 were searched. To conduct meta-analysis, CMA:2 (Comprehensive Meta-analysis) was used.

Results: Finally, 14 articles were included in the study. Pain relief standard difference in mean between-groups was $-1.01\left(95 \% \mathrm{CI}:-1.59\right.$ to $\left.-0.43, \mathrm{Q}=148.5, \mathrm{df}=8, \mathrm{p}=0.02, \mathrm{I}^{2}=76\right)$ this difference was significant $(\mathrm{p}<0.05)$. The overall Apgar score standard difference in mean between-groups (Entonox vs. comparison) was 0.12 (95\% CI: 0.01 to $\left.0.23, \mathrm{Q}=109.4, \mathrm{df}=16, \mathrm{p}=0.00, \mathrm{I}^{2}=85.3\right)$ this difference was significant $(\mathrm{p}<0.05)$. The results of mothers' satisfaction rate show that mothers in Entonox group has a high level of satisfaction rate.

Conclusion: According to results of studies published in Iran, it seems that Entonox is an effective method for pain relief in vaginal delivery, as well as for improving infant Apgar score and mothers' satisfaction rate. Pain relief through Entonox can be used as a strategy for cesarean section reduction plan in Iran.

Keywords: Entonox, Pain relief, Vaginal delivery, Apgar, Satisfaction
\end{abstract}

\section{Introduction}

Pregnancy and childbirth is the most intense and most stressful time of a woman's life, and is always considered one of the main life-threatening factors of their life. Thus, in these risky and stressful periods, women need high-quality care and additional support (1). The mechanism of childbirth is a spontaneous process and without need to the intervention (2) that this action takes places both cesarean and vaginal childbirth (3). Vaginal childbirth is known as the best method of childbirth but unfortunately, in recent years the prevalence of this type of childbirth, due to the

\section{Corresponding author:}

Associate Professor Dr. Morteza Ghojazadeh, Research Center for Evidence Based Medicine (RCEBM), Tabriz University of Medical Sciences, Tabriz, Iran.

Tel: +98.41333373741, Fax: +98.41333373741, Email: as4007@yahoo.com

Received: April 29, 2017, Accepted: October 27, 2017, Published: December 2017

iThenticate screening: July 23, 2017, English editing: November 20, 2017, Quality control: December 12, 2017

(C) 2017 The Authors. This is an open access article under the terms of the Creative Commons Attribution-NonCommercialNoDerivs License, which permits use and distribution in any medium, provided the original work is properly cited, the use is non-commercial and no modifications or adaptations are made. 
spread and popularity of cesarean, has reduced and this has become one of the serious concerns of health authorities (4). One of the main reasons for the decline of natural childbirth is the amount of pain in natural childbirth (5-7). For this purpose, researchers in recent years have made great efforts for the development of natural childbirth methods without pain (8). In no-pain childbirth, midwives and physicians using different methods try to reduce natural childbirth pain for the mother, so that she can give birth more easily and with less pain and suffering (9). There are many ways to reduce child birth pain (10-15). One of the methods is the use of analgesic gas of Entonox. Entonox is a mixture of oxygen gas and nitrous oxide $\left(\mathrm{N}_{2} \mathrm{O}\right)$ and is prescribed through a mask. When during childbirth, she feels uterine contraction as pain, the mask is placed on the mother's face and the mother takes deep breaths through it. Gas enters into the lungs and then to the brain and by effecting the brain's pain centers, reduces the feeling of pain (16-20). In recent years, some studies in Iran investigated the effect of using Entonox in reducing pain and other childbirth indicators $(21,22)$. However, these studies investigated the impact of using Entonox in a small environment and have a smaller sample size. So, transparent and useful information for decision-making and policy at the macro level could not be provided. A systematic summary of results of these studies can provide necessary information to make decisions and policies at the macro level. So, the purpose of this study was to conduct a systematic review and meta-analysis of the effect of using Entonox in pain relief and other indicators of childbirth.

\section{Material and Methods}

\subsection{Research design and search strategy}

This systematic review and meta-analysis study was designed and conducted in 2016 in accordance with the Preferred Reporting Items for Systematic Reviews and Meta-Analyses (PRISMA) approach (23-25). The required data was collected using keywords such as "Entonox", "nitrous oxide", "vaginal delivery", "pain relief", "obstetric", "labor pain", and "labor analgesia", from databases including Google scholar, PubMed, Science Direct, Magiran, SID and Scopus, and hand-searching of related and valid journals and references of articles. Articles published from 2000 to 2016 were searched.

\subsection{Inclusion and exclusion criteria}

The inclusion criteria for entering the articles included: participants including mothers and their infants, intervention included "Entonox" or "nitrous oxide", comparison included other options for pain relief in labor or nonintervention groups, outcome included Apgar score, pain relief and mothers' satisfaction rate. Published articles in English or Persian language and interventional studies were also included in the study. The exclusion criteria consisted of: studies that had no control group, conference and meeting articles, case reports, letters to editors and educational articles.

\subsection{Quality assessment}

The quality of articles was assessment by two researchers using a checklist of stands for Consolidated Standards of Reporting Trials (CONSORT: 2010). The CONSORT evaluating tool is one of the most important and applicable tools for evaluating clinical trial articles, and was introduced in the mid-1990s by a group of experts in clinical trials, statisticians, and epidemiologists as an international strategy and a standard method for reporting clinical trials. Based on the latest version of the checklist's instruction, CONSORT 2010 includes 37 items for evaluating 6 main parts of clinical trial studies. These 6 parts are title and abstract, introduction, materials and methods, results, discussion, and other information.

\subsection{Data extraction}

For extraction of data, in first phase a data extraction table form was developed in Excel: 2010 office software. This extraction table included the following data: name of author, article publication year, sample size, Apgar score, pain relief and mother's satisfaction rate. In the second phase of data, 5 articles were extracted by this form and the problems in the initial form were eliminated. After the extraction table was finalized, required data from selected articles were extracted and summarized in tables.

\subsection{Data analysis}

In order to estimate Apgar score mean, pain relief mean and mothers' satisfaction rate between Entonox and comparison groups, meta-analysis statistical methods were applied. To conduct meta-analysis, CMA:2 (Comprehensive Meta-analysis) was used. To report the results, the forest plot diagrams were used with 95 percent for each study. For evaluation of heterogeneity among the studies' results, Q statistic and $\mathrm{I}^{2}$ indicator were used. In the current study, $\mathrm{I}^{2}$ more than $50 \%$ was determined as criterion of heterogeneity. 


\section{Results}

Out of 296 articles which have been found from literature, finally 14 articles related to the aim of the study were included in the study (Figure 1). Characteristics of included articles' results are summarized in Table1. In the analysis phase of effect of Entonox in pain relief, the result of a Khadem N, et al. (37) study, due to high heterogeneity, was not included in meta-analysis. According to results of included studies to analysis, the pain relief standard difference in mean between groups was -1.01 (95\% CI: -1.59 to $-0.43, \mathrm{Q}=148.5, \mathrm{df}=8, \mathrm{p}=0.02, \mathrm{I}^{2}=76$ ) (Figure 2), this difference was significant $(\mathrm{p}<0.05)$. The overall Apgar score standard difference in mean between groups (Entonox vs. comparison) was $0.12\left(95 \% \mathrm{CI}\right.$ : 0.01 to $\left.0.23, \mathrm{Q}=109.4, \mathrm{df}=16, \mathrm{p}=0.00, \mathrm{I}^{2}=85.3\right)$, this difference was significant $(p<0.05)$. Difference between groups in five-minute Apgar was 0.06 (95\% CI: -0.06 to 0.17 , $\mathrm{Q}=235.6, \mathrm{df}=7, \mathrm{p}=0.00, \mathrm{I}^{2}=89.3$ ), this difference was not significant $(\mathrm{p}>0.05)$. Difference between groups in oneminute Apgar was $0.47\left(95 \% \mathrm{CI}\right.$ : 0.19 to $\left.0.76, \mathrm{Q}=413.7, \mathrm{df}=8, \mathrm{p}=0.00, \mathrm{I}^{2}=97.3\right)$, this difference was significant $(\mathrm{p}<0.05)$ (Figure 3). The results of mothers' satisfaction rate show that, $57.6 \%$ of mothers in Entonox group have a high level of satisfaction rate vase $21.3 \%$ of mothers in comparison group. To evaluate publication bias, a funnel plot was applied (Figure 4). Results of this funnel plot show that there was a possibility of publication bias among the studies.

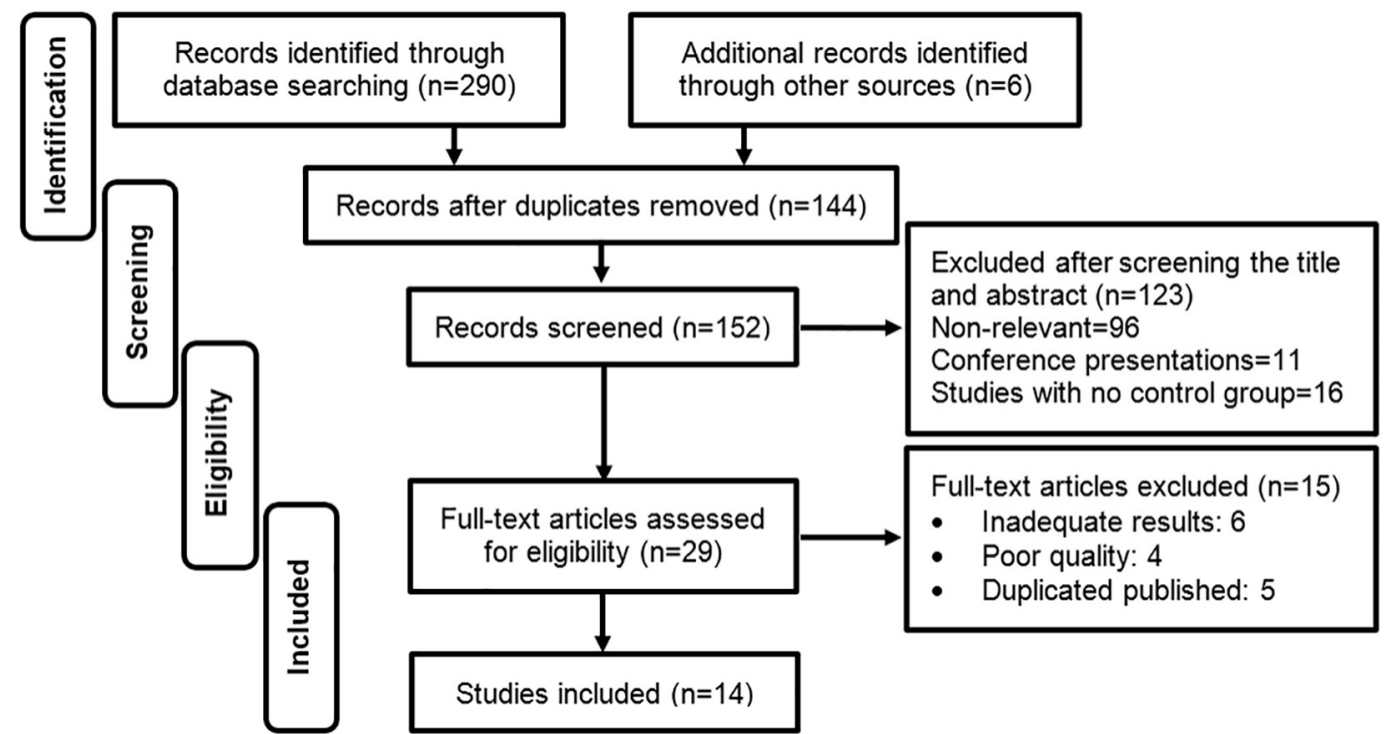

Figure 1. The diagram of articles screening and selection process

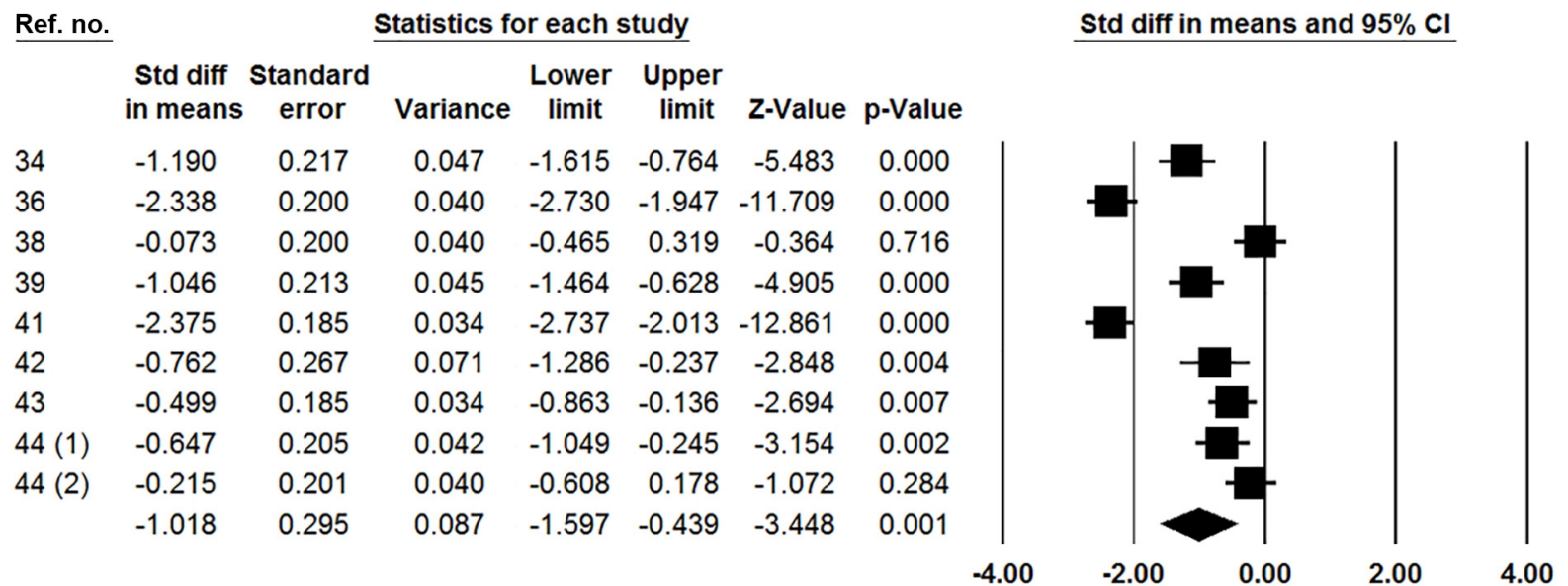

Figure 2. Pain relief standard difference in mean between Entonox vs. comparison 
Table 1. Characteristics of included articles

\begin{tabular}{|c|c|c|c|c|c|c|c|c|}
\hline \multirow{2}{*}{$\begin{array}{l}\text { Ref. } \\
\text { no. }\end{array}$} & \multicolumn{2}{|c|}{ Sample size } & \multicolumn{2}{|l|}{ Apgar } & \multicolumn{2}{|l|}{ Pain relief (VAS) } & \multicolumn{2}{|l|}{ Satisfaction rate } \\
\hline & Entonox & Comparison & Entonox & Comparison & Entonox & Comparison & Entonox & Comparison \\
\hline 33 & 80 & Oxygen $=80$ & $\mathrm{M} 1=8.71 \pm 0.4$ & $\mathrm{M} 1=8.57 \pm 0.6$ & - & - & $\begin{array}{l}\text { High }=71.2 \\
\text { Moderate }=23.4 \\
\text { Low }=4.1 \\
\text { Unsatisfied }=1.3\end{array}$ & $\begin{array}{l}\text { High }=16.9 \\
\text { Moderate=32.5 } \\
\text { Low }=28.6 \\
\text { Unsatisfied=22 }\end{array}$ \\
\hline 34 & 50 & Pethidine $=50$ & - & - & $\begin{array}{l}\text { Before } \\
\text { analgesia }=9.1 \pm 0.9 \\
\text { Over first } \\
\text { stage }=6 \pm 1.5 \\
\text { Over second } \\
\text { stage }=5.7 \pm 1.8 \\
\text { Mean } \pm \text { SD: } 6.9 \pm 1.4\end{array}$ & $\begin{array}{l}\text { Before } \\
\text { analgesia }=9.4 \pm 0.7 \\
\text { Over first } \\
\text { stage }=7.1 \pm 1.2 \\
\text { Over second } \\
\text { stage }=8.2 \pm 1 \\
\text { Mean } \pm \text { SD: } 8.3 \pm 0.9\end{array}$ & $\begin{array}{l}\text { High }=46 \\
\text { Moderate }=32 \\
\text { Low }=20 \\
\text { Unsatisfied }=2\end{array}$ & $\begin{array}{l}\text { High }=28 \\
\text { Moderate }=36 \\
\text { Low }=28 \\
\text { Unsatisfied }=8\end{array}$ \\
\hline 35 & 49 & $\begin{array}{l}\text { No } \\
\text { intervention }=45\end{array}$ & - & - & - & - & $\begin{array}{l}\text { High }=49 \\
\text { Moderate }=28.6 \\
\text { Low }=20.4 \\
\text { Unsatisfied=2 }\end{array}$ & $\begin{array}{l}\text { High }=22.4 \\
\text { Moderate }=42.9 \\
\text { Low }=24.5 \\
\text { Unsatisfied }=10.2\end{array}$ \\
\hline 36 & 76 & Oxygen $=94$ & - & - & $5.1 \pm 1.2$ & $8.9 \pm 1.9$ & - & - \\
\hline 37 & 42 & Epidural $=42$ & $\begin{array}{l}\mathrm{M} 1=8.4 \\
\mathrm{M} 5=8.8\end{array}$ & $\begin{array}{l}M 1=8.5 \\
M 5=8.8\end{array}$ & $\begin{array}{l}\text { Before analgesia }=5.8 \\
\text { Over first stage }=7.7 \\
\text { Over second } \\
\text { stage }=9.5 \\
\text { Mean } \pm \text { SD:7.6 }\end{array}$ & $\begin{array}{l}\text { Before analgesia }=1.2 \\
\text { Over first stage }=1.5 \\
\text { Over second } \\
\text { stage }=1.6 \\
\text { Mean } \pm \text { SD: } 1.4\end{array}$ & - & - \\
\hline 38 & 50 & Pethidine $=50$ & $\begin{array}{l}\mathrm{M} 1=9 \pm 0.3 \\
\mathrm{M} 5=9.9 \pm 0.4\end{array}$ & $\begin{array}{l}\mathrm{M} 1=8 \pm 0.9 \\
\mathrm{M} 5=9.8 \pm 0.2\end{array}$ & $\begin{array}{l}\text { Before } \\
\text { analgesia }=7.3 \pm 2 \\
\text { Over first } \\
\text { stage }=3.9 \pm 1.4 \\
\text { Over second } \\
\text { stage }=5 \pm 1.4 \\
\text { Mean } \pm \text { SD: } 5.7 \pm 1.6\end{array}$ & $\begin{array}{l}\text { Before } \\
\text { analgesia }=7.3 \pm 1.1 \\
\text { Over first } \\
\text { stage }=5.6 \pm 1.1 \\
\text { Over second } \\
\text { stage }=4.7 \pm 1.1 \\
\text { Mean } \pm \text { SD:5.8 } \pm 1.1\end{array}$ & & \\
\hline 39 & 50 & $\begin{array}{l}\text { No } \\
\text { intervention }=50\end{array}$ & $\begin{array}{l}\text { M1 }=9.1 \pm 0.3 \\
\text { M5 }=9.9 \pm 0.3\end{array}$ & $\begin{array}{l}\text { M1 }=8.9 \pm 0.3 \\
\text { M5 }=9.8 \pm 0.6\end{array}$ & $5.3 \pm 1.2$ & $6.9 \pm 1.8$ & - & - \\
\hline 40 & 135 & $\begin{array}{l}\text { No } \\
\text { intervention= } \\
135 \\
\end{array}$ & $\begin{array}{l}\mathrm{M} 1=9 \pm 0.7 \\
\mathrm{M} 5=9.7 \pm 0.4\end{array}$ & $\begin{array}{l}\mathrm{M} 1=9.1 \pm 0.6 \\
\mathrm{M} 5=9.8 \pm 0.4\end{array}$ & - & - & - & - \\
\hline 41 & 100 & $\begin{array}{l}\text { No } \\
\text { intervention= } \\
100\end{array}$ & $\begin{array}{l}\mathrm{M} 1=9.1 \\
\mathrm{M} 5=9.8\end{array}$ & $\begin{array}{l}M 1=8.9 \\
M 5=9.7\end{array}$ & $5 \pm 1.6$ & $8.8 \pm 1.6$ & $\begin{array}{l}\text { High }=64 \\
\text { Moderate }=25 \\
\text { Low }=7 \\
\text { Unsatisfied }=4\end{array}$ & $\begin{array}{l}\text { High }=18 \\
\text { Moderate }=30 \\
\text { Low }=27 \\
\text { Unsatisfied }=25\end{array}$ \\
\hline 42 & 30 & $\begin{array}{l}\text { No } \\
\text { intervention }=30\end{array}$ & - & - & $5.6 \pm 1.5$ & $7.8 \pm 3.8$ & - & - \\
\hline 43 & 60 & Oxygen $=60$ & - & - & $5.8 \pm 1.9$ & $6.8 \pm 2.1$ & - & - \\
\hline $\begin{array}{l}44, \\
1\end{array}$ & 50 & $\begin{array}{l}\text { Warm } \\
\text { water }=50\end{array}$ & $\begin{array}{l}\mathrm{M} 1=9.2 \pm 0.5 \\
\mathrm{M} 5=10 \pm 0.5\end{array}$ & $\begin{array}{l}\mathrm{M} 1=8.8 \pm 0.3 \\
\mathrm{M} 5=10 \pm 0.5\end{array}$ & $\begin{array}{l}\text { Before } \\
\text { analgesia }=6.3 \pm 1.7 \\
\text { Over first } \\
\text { stage }=4.8 \pm 1.8 \\
\text { Over second } \\
\text { stage }=4.32 \pm 1.6 \\
\text { Mean } \pm \text { SD: } 5.1 \pm 1.7\end{array}$ & $\begin{array}{l}\text { Before } \\
\text { analgesia }=6.6 \pm 1.5 \\
\text { Over first } \\
\text { stage }=5.7 \pm 1.8 \\
\text { Over second } \\
\text { stage }=6.4 \pm 2 \\
\text { Mean } \pm \text { SD: } 6.2 \pm 1.7\end{array}$ & - & - \\
\hline $\begin{array}{l}44, \\
2\end{array}$ & 50 & $\begin{array}{l}\text { No } \\
\text { intervention }=50\end{array}$ & $\begin{array}{l}\text { M1 }=9.2 \pm 0.5 \\
\text { M5 }=10 \pm 0.5\end{array}$ & $\begin{array}{l}\text { M1 }=8.7 \pm 0.6 \\
\text { M5 }=10 \pm 0.5\end{array}$ & $\begin{array}{l}\text { Before } \\
\text { analgesia }=6.3 \pm 1.7 \\
\text { Over first } \\
\text { stage }=4.8 \pm 1.8 \\
\text { Over second } \\
\text { stage }=4.32 \pm 1.6 \\
\text { Mean } \pm \text { SD }: 5.1 \pm 1.7\end{array}$ & $\begin{array}{l}\text { Before } \\
\text { analgesia }=4.8 \pm 0.9 \\
\text { Over first } \\
\text { stage }=5.4 \pm 1.1 \\
\text { Over second } \\
\text { stage }=7.4 \pm 1.1 \\
\text { Mean } \pm \text { SD: } 5.4 \pm 1 \\
\end{array}$ & - & - \\
\hline 45 & 250 & $\begin{array}{l}\text { No } \\
\text { intervention= } \\
250\end{array}$ & $\begin{array}{l}\mathrm{M} 1=8.5 \pm 0.9 \\
\mathrm{M} 5=9.5 \pm 0.8\end{array}$ & $\begin{array}{l}\mathrm{M} 1=8.5 \pm 0.8 \\
\mathrm{M} 5=9.5 \pm 0.7\end{array}$ & - & - & - & - \\
\hline
\end{tabular}

$\mathrm{VAS}=$ visual analog scale $\mathrm{M} 1=$ minute one; $\mathrm{M} 5=$ minute five 


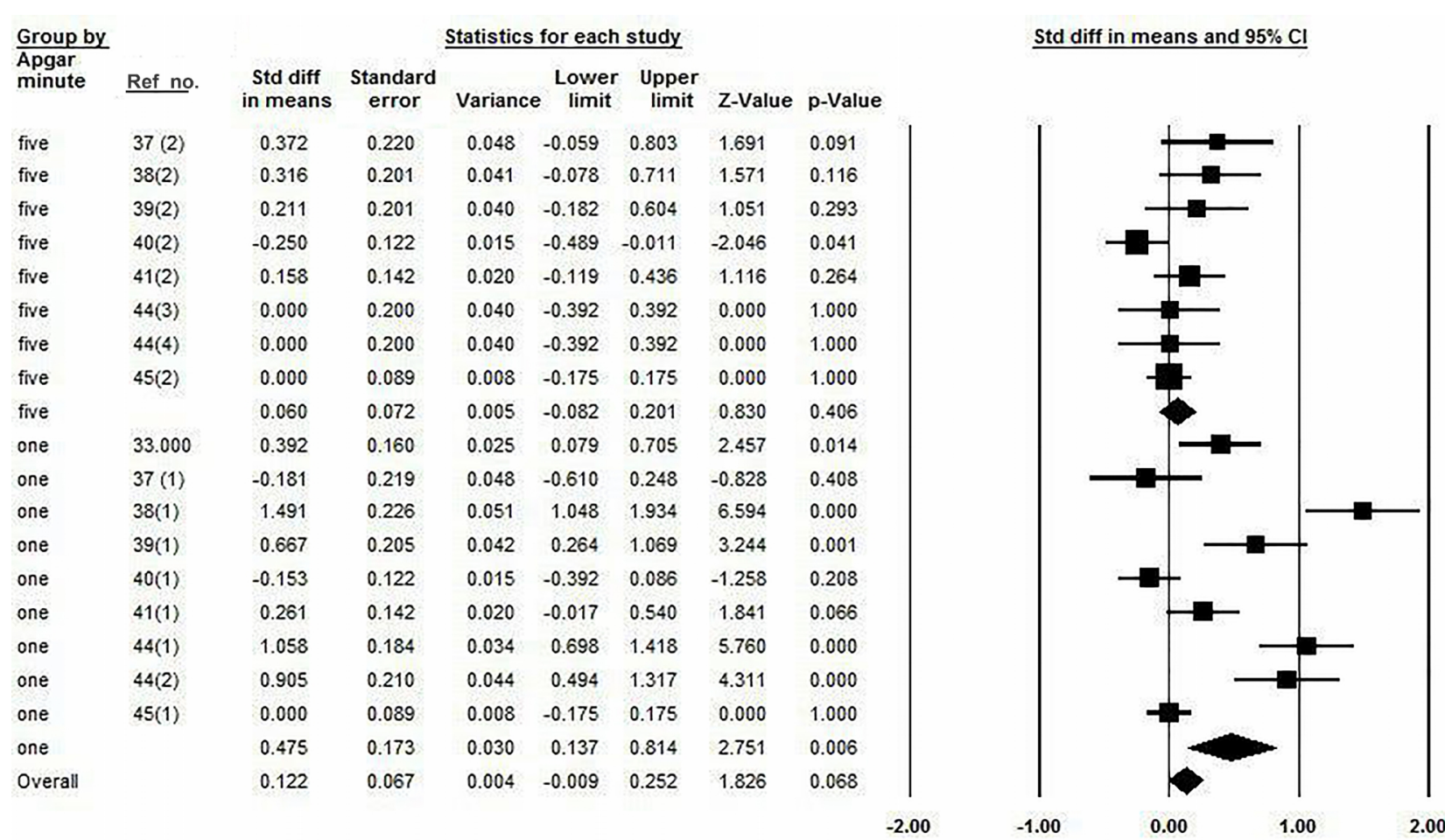

Figure 3. Apgar score standard difference in mean between Entonox vs. comparison

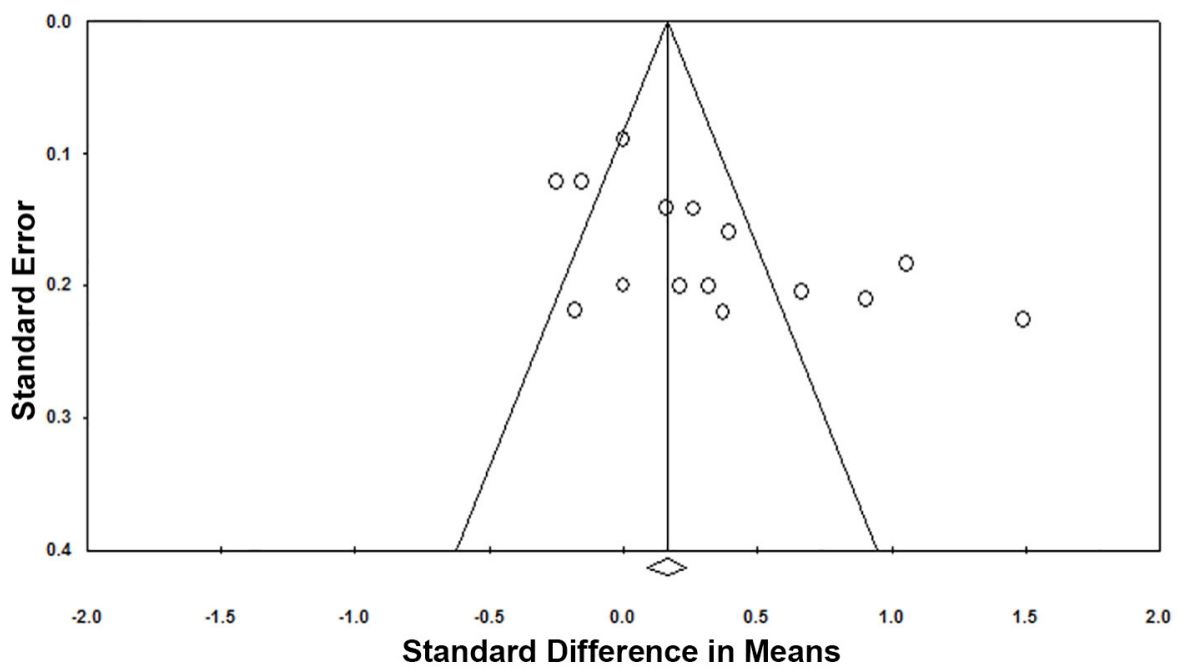

Figure 4. Funnel plot of standard error by standard difference in means

\section{Discussion}

Pain relief standard difference in mean between groups was significantly different $(p<0.05)$. The results of mothers' satisfaction rate show that, mothers in Entonox have a high level of satisfaction rate. The results showed Entonox has a significant effect in reducing childbirth pain. According to the study of the College of Obstetrics and Gynecology of Australia in New Zealand, around 70 percent of women have had pain relief with Entonox (26). In a study by Soyannow et al. that was conducted on 150 Nigerian women, it was shown that Entonox has significant effect in reducing childbirth pain (27). In a research conducted by Rosen on 400 pregnant women in America in 2004, it showed that Entonox is significantly effective in reducing childbirth pain (28). Despite the availability of other methods to reduce childbirth pain, for three main reasons Entonox is one of the most widely used methods. These three reasons include: rapid elimination from the body, absence of expensive, complex equipment and specialized personnel and finally, the general well-being and satisfaction of the mother, although the administration 
should be under the supervision of trained personnel (20). Results of this study showed that Apgar score of babies whose mothers used Entonox gas during childbirth was significantly better than comparison groups. Results of different studies have also shown that Apgar score of babies whose mothers used Entonox gas during childbirth was better than comparison groups $(21,29)$. In the research of Volmanen in 2005, the results did not show a significant difference between Apgar score of babies whose mothers had used the Entonox compared with Apgar score of babies whose mothers had used remifentanil (30). Considering the impact of pain on reducing blood supply to the mother's womb and fetus, more Apgar score of babies in Entonox method according to further reduce of the mother's pain is justified. The results showed that the mother in the Entonox group in comparison with other methods of reducing childbirth pain, had a higher level of satisfaction. Dann et al reported that 96.8 percent of those who used Entonox to induce analgesia in childbirth again had the tendency to use Entonox (31). Rosen also, in his review study, has noted that childbirth satisfaction with reducing pain and lack of severe side effects has had a positive correlation. He reported the desire to reuse Entonox in future childbirth in $80 \%$ of those who had used the gas (32). The use of pain relief methods to ease childbirth pain is common in most countries. Eighty-one percent of women who give birth in the United States used one of the methods of drug analgesia, and $19 \%$ of others used a large number of non-pharmacological methods; in European countries, this figure reaches $90 \%$. Despite the simple and available methods of painless childbirth, it seems that using these methods in Iran, due to the lack of knowledge of the benefits and possible side effects of these methods, are not common. According to World Health Organization recommendations and policies of the Ministry of Health, Treatment and Medical Education in order to reduce the rate of cesarean without medical indication of mothers to be encouraged to natural childbirth and while they are deprived of the benefits of painless natural childbirth. The mean limitation of this study was lack of access to detailed data in some papers. Because some papers did not report detailed results, extracting the intended data from those papers was impossible. Future studies in this area should consider this issue when conducting and reporting the study.

\section{Conclusions}

Based on the results of the study published in Iran that are investigated in the present study, it can be said that the use of Entonox gas is an effective method for reducing the amount of childbirth pain, and in addition to reducing pain, the Apgar score and satisfaction in women also has positive results. Therefore, given the high rate of cesarean in Iran, which, it appears, one of the reasons is the fear of natural childbirth pain, development of painless childbirth methods such as using Entonox, can have a positive effect in reducing cesarean.

\section{Acknowledgments:}

This research was supported by the Research Center for Evidence Based Medicine (RCEBM), Tabriz University of Medical Sciences, Tabriz, Iran.

\section{Conflict of Interest:}

There is no conflict of interest to be declared.

\section{Authors' contributions:}

All authors contributed to this project and article equally. All authors read and approved the final manuscript.

\section{References:}

1) Page L. The new midwifery science and sensitivity in practice. London: Churchill Livingstone; 2000.

2) David H, Norman J. Gynecology illustrated. London: Churchill Livingstone Co; 2000.

3) Cunningham F, Leveno K, Bloom S, Fauser J, Zwirner M. Williams Obstetrics. New York: Graw-Hill; 2005.

4) Azami-Aghdash S, Ghojazadeh M, Dehdilani N, Mohammadi M, Asl Amin Abad R. Prevalence and causes of cesarean section in Iran: Systematic review and meta-analysis. Iranian Journal of Public Health. 2014; 43(5): 545-55. PMID: 26060756.

5) Castro TV, Franceschini SA, Poli-Neto O, Ferriani RA, Silva de Sa MF, Vieira CS. Effect of intracervical anesthesia on pain associated with the insertion of the levonorgestrel-releasing intrauterine system in women without previous vaginal delivery: a RCT. Human reproduction (Oxford, England). 2014; 29(11): 2439-45. doi: 10.1093/humrep/deu233. PMID: 25240012.

6) Kargar R, Aghazadeh-Nainie A, Khoddami-Vishteh HR. Comparison of the Effects of Lidocaine Prilocaine Cream (EMLA) and Lidocaine Injection on Reduction of Perineal Pain During Perineum Repair in Normal Vaginal Delivery. Journal of family \& reproductive health. 2016; 10(1): 21-6. PMID: 27385970 
7) Morais I, Lemos A, Katz L, Melo LF, Maciel MM, Amorim MM. Perineal Pain Management with Cryotherapy after Vaginal Delivery: A Randomized Clinical Trial. Rev Bras Ginecol Obstet. 2016; 38(7): 325-32. doi: 10.1055/s-0036-1584941. PMID: 27427867.

8) Hashizume M, Shimoda T, Sasaki S, Kunii O, Caypil W, Dauletbaev D, et al. Anaemia in relation to low bioavailability of dietary iron among school-aged children in the Aral Sea region, Kazakhstan. Int J Food Sci Nutr. 2004; 55(1): 37-43. doi: 10.1080/09637480310001642466. PMID: 14630590.

9) Tournaire M. Alternative approaches to pain relief during labor and delivery. Advances in experimental medicine and biology. 2004; 546: 193-206. PMID: 15584375.

10) Borup L, Wurlitzer W, Hedegaard M, Kesmodel US, Hvidman L. Acupuncture as pain relief during delivery: a randomized controlled trial. Birth (Berkeley, Calif). 2009; 36(1): 5-12. doi: 10.1111/j.1523536X.2008.00290.x. PMID: 19278378.

11) Leppert W, Krajnik M, Wordliczek J. Delivery systems of opioid analgesics for pain relief: a review. Current pharmaceutical design. 2013; 19(41): 7271-93. PMID: 23489205.

12) Patel D, Naik S, Chuttani K, Mathur R, Mishra AK, Misra A. Intranasal delivery of cyclobenzaprine hydrochloride-loaded thiolated chitosan nanoparticles for pain relief. Journal of drug targeting. 2013; 21(8): 759-69. doi: 10.3109/1061186X.2013.818676. PMID: 23879335.

13) Simavli S, Kaygusuz I, Gumus I, Usluogullari B, Yildirim M, Kafali H. Effect of music therapy during vaginal delivery on postpartum pain relief and mental health. Journal of affective disorders. 2014; 156: 194-9. doi: 10.1016/j.jad.2013.12.027. PMID: 24411681.

14) Singer J, Jank A, Amara S, Stepan PD, Kaisers U, Hoehne C. Efficacy and Effects of Parenteral Pethidine or Meptazinol and Regional Analgesia for Pain Relief during Delivery. A Comparative Observational Study. Geburtshilfe Frauenheilkd. 2016; 76(9): 964-71. doi: 10.1055/s-0042-111009. PMID: 27681521.

15) Xie J, Xiao D, Zhao J, Hu N, Bao Q, Jiang L, et al. Mesoporous Silica Particles as a Multifunctional Delivery System for Pain Relief in Experimental Neuropathy. Advanced healthcare materials. 2016; 5(10): 1213-21. doi: 10.1002/adhm.201500996. PMID: 27028159.

16) Clyburn P. The use of Entonox for labour pain should be abandoned. Int J Obstet Anesth. 2001; 10(1): 279. doi: 10.1054/ijoa.2000.0821. PMID: 15321648.

17) Lyons A. How to ... administer Entonox. Midwives. 2011; 14(2): 24. PMID: 24888000

18) Najafi TF, Bahri N, Ebrahimipour H, Najar AV, Taleghani YM. Risk Assessment of Using Entonox for the Relief of Labor Pain: A Healthcare Failure Modes and Effects Analysis Approach. Electron physician. 2016; 8(3): 2150-9. doi: 10.19082/2150. PMID: 27123224.

19) Varposhti MR, Ahmadi N, Masoodifar M, Shahshahan Z, Tabatabaie MH. Comparison of remifentanil: Entonox with Entonox alone in labor analgesia. Advanced biomedical research. 2013; 2: 87. doi: 10.4103/2277-9175.122511. PMID: 24524033.

20) Yeo ST, Holdcroft A, Yentis SM, Stewart A, Bassett P. Analgesia with sevoflurane during labour: ii. Sevoflurane compared with Entonox for labour analgesia. Br J Anaesth. 2007; 98(1): 110-5. doi: 10.1093/bja/ael327. PMID: 17158129.

21) Agah J, Baghani R, Safiabadi Tali SH, Tabarraei Y. Effects of continuous use of Entonox in comparison with intermittent method on obstetric outcomes: a randomized clinical trial. Journal of pregnancy. 2014; 2014: 245907. doi: 10.1155/2014/245907. PMID: 25525519.

22) Esfandiari M, karimi S. Effectiveness of Entonox on Severity of Labor Pain in Women Referred to Maternity Ward of Imam Reza hospital Kermanshah 2007. sjimu. 2009; 17(1): 25-30.

23) Moher D, Liberati A, Tetzlaff J, Altman DG. Preferred reporting items for systematic reviews and metaanalyses: the PRISMA statement. Ann Intern Med. 2009; 151(4): 264-9. doi: 10.7326/0003-4819-151-4200908180-00135. PMID: 19622511.

24) Moher D, Liberati A, Tetzlaff J, Altman DG. Preferred reporting items for systematic reviews and metaanalyses: the PRISMA statement. PLoS Med. 2009; 6(7):21. doi: 10.1371/journal.pmed.1000097. PMID: 19621072.

25) Moher D, Liberati A, Tetzlaff J, Altman DG. Preferred reporting items for systematic reviews and metaanalyses: the PRISMA Statement. Open Med. 2009; 3(3): 21. PMID: 21603045.

26) Carstoniu J, Levytam S, Norman P, Daley D, Katz Y, Sandler A. Nitrous Oxide in early labor. Safety and analgesic efficacy assessed by a double- blind, placebo- controlled study. Anesthesiology 1994; 80(1): 305. PMID: 8291726.

27) Soyannwo O. Self-administered Entonox in labour: report of experience in Ibadan. Afr J Med Neel Sci. 2006; 14(1-2): 95-8. PMID: 2994447.

28) Rosen M. Relief of labor pain. Am J Obstet Gynecol. 2004: 110-21. 
29) Rooks JP. Labor pain management other than neuraxial: what do we know and where do we go next? Birth (Berkeley, Calif). 2012; 39(4): 318-22. doi: 10.1111/birt.12009. PMID: 23281953.

30) Volmanen E. Comparsion of Remifentanil and Nitro oxide in labor. Actaa Anaesthesiological Scandinavia Journal. 2005; 49(4): 453-8. doi: 10.1111/j.1399-6576.2005.00639.x. PMID: 15777291.

31) Dunen I, Rooks J. Use of nitrous oxide in midwifery practice - complementary, synergistic, and needed in the united states. Journal of Midwifery \& Women's Health. 2007; 52(3): 186-9. doi: 10.1016/j.jmwh.2007.02.017. PMID: 17467584.

32) Rosen M. Nitrous oxide for relief of labor pain: a systematic review. Am J Obstet Gynecol. 2002; 186: S110-260. doi: 10.1016/S0002-9378(02)70186-5. PMID: 12011877.

33) Rezaeipour A, Idenloo F, Khakbazan Z, Kazemnejad K. The effects of Entonox on implication of painless labor and delivery satisfaction rate among pregnant women. Hayat. 2008; 13(4): 45-58.

34) Teimoori B, Sakhavar N, Mirteimoori M, Narouie B, Ghasemi-rad M. Nitrous Oxide versus Pethidine with Promethasine for Reducing Labor Pain. Gynecol Obstetric 2011; 1(1): 1-4. doi: 10.4172/21610932.1000106.

35) Pasha H, Basirat Z, Hajahmadi M, Bakhtiari A, Faramarzi M, Salmalian H. Maternal Expectations and Experiences of Labor Analgesia With Nitrous Oxide. Iran Red Cres Med J. 2012; 14(12): 792-7. doi: 10.5812/ircmj.3470. PMID: 23483128.

36) Najefian M, Cheraghi M, Pourmehdi Z, Nejad AD. The effect of nitrous oxide (ENTONOX) on labour pain relief during delivery stages. International Journal of Pharmacy \& Therapeutics. 2013; 4: 242-6. doi: $10.18203 / 2320-1770$.

37) Khadem N, Zirak N, Soltani G, Sahebdelfar N, Sepehri Shamloo A, Ebrahimzadeh S. Comparison of Epidural versus Entonox for Labor Analgesia in Nulliparous Women. Journal of Surgery and Trauma. 2013; 1(1): 1-5.

38) Mobaraki N, Yousefian M, Seifi S, Sakaki M. A Randomized Controlled Trial Comparing Use of Enthonox With Pethidine for Pain Relief in Primigravid Women During the Active Phase of Labor. Anesth Pain Med. 2016; 6(4): e37420. doi: 10.5812/aapm.37420. PMID: 27843776.

39) Salehian T, Safdari F, Jahantighi S. The Effect of Entonox on Labor Pain and Outcome of Delivery in Primiparous in Iranshahr, Iran (2009). Journal Of Research Development in Nursing \& Midwifery. 2010; 7(1): 1-9.

40) Yazdi Moghaddam H, Rahnamai Rahsepar F, Heidari A. Studying the Effect of Entonox Gas on the APGAR of the Neonates. Journal of Rafsanjan University of Medical Sciences. 2011; 10(3): 165-74.

41) Mohammad Jaafari R, Torabzadeh Bafghi V, Torabzadeh Bafghi A. The Effect of Entonox gas Inhalation on the Duration of Active Phase of Labor and Outcome of Delivery. Jundishapur Sci Med J. 2013; 12(1): 13-9.

42) Jafarzadeh L, Shabanian S, Jafari F, Gangi F. The effect of Entonox on severity of pain and mother hemodynamic and fetus apgar in natural vaginal delivery. J Sharekord Univ Med Sci. 2012; 14(3): 92-9.

43) Saghiri M, Sattarzadeh N, Tabrizi N, Pezeshki ZA. A Comparative Study on the Severity of Labor Pain with or without Entonox and it's effects on the new-borns of Primiparas. Journal of Ardabil University of Medical Sciences. 2008; 8(1): 62-7.

44) Masoudi M, Akbari S. The comparison of Entonox and warm water effect on labor pain. Yafte. 2011; 12(2): 25-32.

45) Talebi H, Nourozi A, Jamilian M, Baharfar N, Eghtesadi-Araghi P. Entonox for labor pain: A randomized placebo controlled trial. Pak J Biol Sci. 2009; 12(17): 1217-21. PMID: 19943458. 